\title{
Retraction Note to: Antimicrobial misuse in pediatric urinary tract infections: recurrences and renal scarring
}

Jayaweera Arachchige Asela Sampath Jayaweera ${ }^{1 *}$ (i) and Mohommed Reyes ${ }^{2}$

\section{Retraction Note to:}

Ann Clin Microbiol Antimicrob (2018) 17:27

https://doi.org/10.1186/s12941-018-0279-4

The Editors-in-Chief have retracted this article. Contrary to the statement in the article, the authors subsequently stated that they did not obtain ethics approval for this study. Both authors agree with this retraction.

\section{Publisher's Note}

Springer Nature remains neutral with regard to jurisdictional claims in published maps and institutional affiliations.

\author{
Author details \\ ${ }^{1}$ Department of Microbiology, Faculty of Medicine and Allied Sciences, \\ Rajarata University of Sri Lanka, Saliyapura, Sri Lanka. ${ }^{2}$ Department of Pedi- \\ actrics, Faculty of Medicine and Allied Sciences, Rajarata University of Sri Lanka, \\ Saliyapura, Sri Lanka.
}

Published online: 25 March 2021

The original article can be found online at https://doi.org/10.1186/s12941018-0279-4.

*Correspondence: jaas820703@yahoo.com; jaasjayaweera@rjt.med.ac.lk ${ }^{1}$ Department of Microbiology, Faculty of Medicine and Allied Sciences, Rajarata University of Sri Lanka, Saliyapura, Sri Lanka

Full list of author information is available at the end of the article

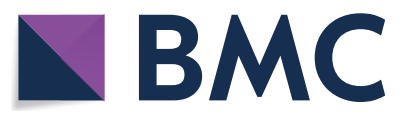

Aur(s) 2021. This article is licensed under a Creative Comm Attribution 4 . Internationa license, which permits use, sharing, adaptation, distribution and reproduction in any medium or format, as long as you give appropriate credit to the original author(s) and the source, provide a link to the Creative Commons licence, and indicate if changes were made. The images or other third party material in this article are included in the article's Creative Commons licence, unless indicated otherwise in a credit line to the material. If material is not included in the article's Creative Commons licence and your intended use is not permitted by statutory regulation or exceeds the permitted use, you will need to obtain permission directly from the copyright holder. To view a copy of this licence, visit http://creativeco mmons.org/licenses/by/4.0/. The Creative Commons Public Domain Dedication waiver (http://creativecommons.org/publicdomain/ zero/1.0/) applies to the data made available in this article, unless otherwise stated in a credit line to the data. 